\title{
Groundwater Quality in the South Coast Interior Basins, California
}

Groundwater provides more than 40 percent of California's drinking water. To protect this vital resource, the State of California created the Groundwater Ambient Monitoring and Assessment (GAMA) Program. The Priority Basin Project of the GAMA Program provides a comprehensive assessment of the State's untreated groundwater quality and increases public access to groundwater-quality information. The South Coast Interior Basins constitute one of the study units being evaluated.

\section{The South Coast Interior Basins Study Unit}

The South Coast Interior Basins (SCI) study unit covers approximately 653 square miles and consists of the Livermore, Gilroy-Hollister, Cuyama Vall ey, Castac Lake Valley, Cuddy Canyon Valley, Cuddy Ranch A rea, Cuddy Valley, and M il Potrero groundwater basins (California Department of Water Resources, 2003). These basins were grouped into three study areas based on geography: Livermore (LIV), Gilroy (GIL), and Cuyama (CUY) (M athany and others, 2009).

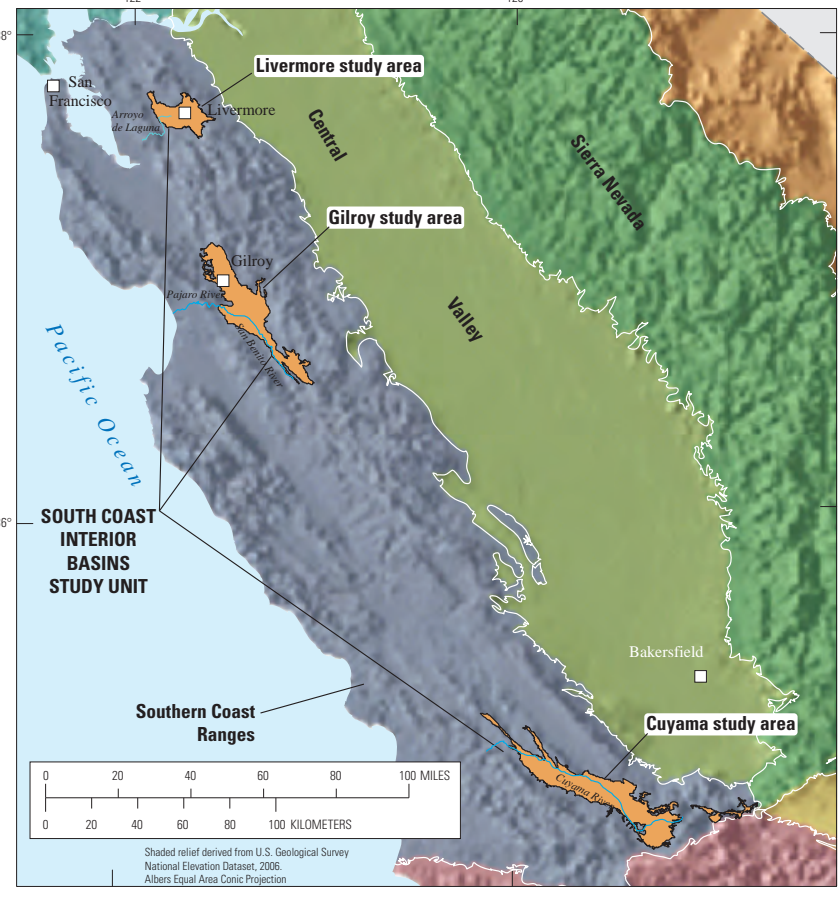

Average annual precipitation across the study unit varies among the three study areas- from more than 20 inches (in.) along the northw est margin of the LIV study area to less than 8 in. in the northern parts of the CUY study area. The study areas are drained by the A rroyo de la Laguna canal in LIV, the Pájaro River and the San B enito River in GIL, and the Cuyama River in CUY. The primary aquifer system consists of Plio-Pleistocene sedimentary formations, Tertiary to Holocene-age alluvial sedimentary sequences, and unconfined Holocene-age and Pleistoceneage alluvium. The primary aquifer system is defined as those parts of the aquifers corresponding to the perforated intervals of the public-supply wells listed in the California Department of Public Health (CDPH) database. Public-supply wells in the study unit are typically drilled to depths between 200 and 600 feet, consist of solid casing from the land surface to a depth of about 50 to 350 feet, and are perforated bel ow the solid casing. Water quality in the primary aquifer system may differ from that in the shallower and deeper parts of the aquifer system.

L and use within 500-meter buffer areas around the wells in the study unit is approximately 44 percent (\%) agricultural, 29\% urban, and 27\% natural. A gricultural lands are mostly orchards, row crops, vineyards, or pastures. The largest urban areas are the cities of Livermore and Gilroy.

Recharge to groundwater basins occurs as infiltration of spring and streamflow, direct infiltration of precipitation and irrigation, subsurface inflow, and engineered recharge (percolation ponds and river regulation). The primary sources of groundwater discharge are water pumped for irrigation and municipal supply, discharge to rivers and streams, and evaporation.

\section{Overview of Water Quality}

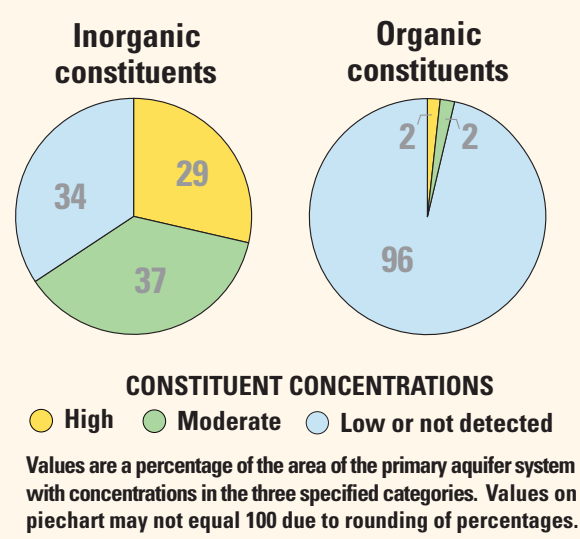

GA M A's Priority Basin Project evaluates the quality of untreated groundwater. However, for context, benchmarks established for drinking-water quality are used for comparison. B enchmarks and definitions of high, moderate, and low concentrations are discussed in the inset box on page 3.

$M$ any inorganic constituents occur naturally in groundwater. The concentrations of the inorganic constituents in groundwater can be affected by natural processes as well as by human activities. In the $\mathrm{SCI}$ study unit, one or more inorganic constituents with human-health benchmarks were present at high concentrations in about $29 \%$ of the primary aquifer system and at moderate concentrations in about $37 \%$.

Human-made organic constituents can be found in products used in the home, business, industry, and agriculture, and can enter the environment through normal usage, spills, or improper disposal. In the $\mathrm{SCl}$ study unit, one or more organic constituents were present at high concentrations in about $2 \%$ of the primary aquifer system and at moderate concentrations in about $2 \%$. 


\section{RESULTS: Groundwater Quality in the South Coast Interior Basins Study Unit}

\section{INORGANIC CONSTITUENTS}
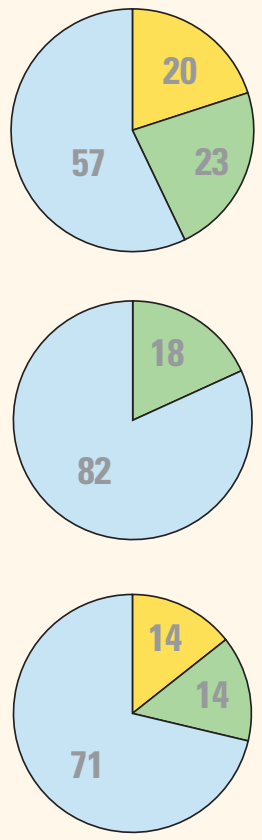

\section{Uranium and radioactive constituents}

\section{Nutrients}
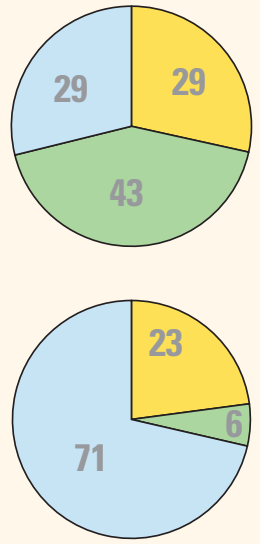

\section{Inorganic Constituents with Health-Based Benchmarks}

Trace and minor elements are naturally present in the minerals in rocks and soils and in the water that comes into contact with those materials. In the $\mathrm{SCl}$ study unit, trace and minor elements were detected at high concentrations in about $20 \%$ of the primary aquifer system and at moderate concentrations in about $23 \%$. A rsenic, boron, and molybdenum were the trace elements that were most frequently detected at high concentrations.

Radioactivity is the release of energy or energetic particles during spontaneous decay of unstable atoms. M ost of the radioactivity in groundwater comes from the decay of naturally occurring isotopes of uranium and thorium in minerals in the sediments of the aquifer. Radioactive constituents were not present at high concentrations in the primary aquifer system and were present at moderate concentrations in about $18 \%$.

Nutrients, such as nitrate and nitrite, can be naturally present at low concentrations in groundwater. High and moderate concentrations generally occur as a result of human activities, such as applying fertilizer to crops. Livestock, when in concentrated numbers, and septic systems al so produce nitrogenous waste that can leach into groundwater. Nitrate was present at high concentrations in about $14 \%$ of the primary aquifer system and at moderate concentrations in about $14 \%$.

\section{Inorganic Constituents with Non-Health Benchmarks}

(Not included in water-quality overview charts shown on the front page)

Some constituents, such as total dissolved solids (TDS), can affect the aesthetic properties of water, such as taste, color, and odor, or may create nuisance problems, such as staining and scaling. All water naturally contains TDS as a result of the weathering and dissolution of minerals in soils. The State of California has a recommended and an upper limit for TDS in drinking water. In the SCI study unit, TDS was present at high concentrations (greater than the upper limit) in 29\% of the primary aquifer system and at moderate concentrations (between the upper and recommended limits) in 43\%. M ost of the sites with high concentrations of TDS also had high concentrations of sulfate.

A noxic conditions (low amounts of dissolved oxygen) in groundwater may result in release of naturally occurring elements such as iron and manganese from minerals into groundwater. Iron, or manganese, or both were present at high concentrations in $23 \%$ of the primary aquifer system.

\section{Constitutient of Special Interest: Perchlorate}

(Not included in water-quality overview charts shown on the front page)

Perchlorate is an inorganic constituent that has been regulated in California drinking water since 2007. It is an ingredient in rocket fuel, fireworks, safety flares and other products, may be present in some fertilizers, and also occurs at low concentrations under natural conditions in groundwater. Perchlorate was detected at high concentrations in $<1 \%$ of the primary aquifer system and at moderate concentrations in about $34 \%$. 


\section{RESULTS: Groundwater Quality in the South Coast Interior Basins Study Unit}

\section{ORGANIC CONSTITUENTS}
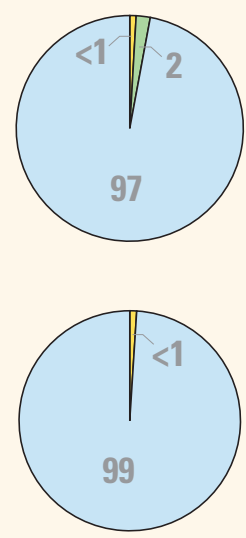

\section{Trihalomethanes}

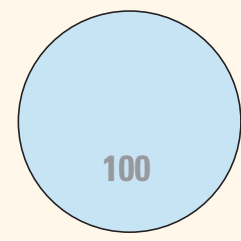

Other VOCs

\section{Organic Constituents}

The Priority Basin Project uses laboratory methods that can detect volatile organic compounds (VOCs) and pesticides at low concentrations far below human-health benchmarks. VOCs and pesticides detected at these low concentrations can be used to trace water from the landscape into the aquifer system.

\section{Volatile Organic Compounds with Human-Health Benchmarks}

VOCS, which include solvents and trihal omethanes, are in many household, commercial, industrial, and agricultural products and are characterized by their tendency to volatilize (evaporate) into the air.

Solvents are used for a number of purposes, including manufacturing and cleaning. In the $\mathrm{SCl}$ study unit, solvents were present at high concentrations in $<1 \%$ of the primary aquifer system. The solvent detected at high concentrations was tetrachloroethene (PCE). Solvents were present at moderate concentrations in about $2 \%$ of the primary aquifer system and were low or not detected in about $97 \%$.

Trihalomethanes may form during municipal water purification and can enter groundwater by the infiltration of landscape irrigation water. One trihal omethane, bromoform, was detected at high concentrations in $<1 \%$ of the primary aquifer system. Trihal omethanes were present at low concentrations, or were not detected, in about $99 \%$ of the primary aquifer system.

Other volatile organic compounds, including organic synthesis reagents, refrigerants, and gasoline additives, were not detected at either high or moderate concentrations.

\section{Pesticides with Human-Health Benchmarks}

Pesticides, which include herbicides, insecticides, and fumigants, are applied to crops, gardens, lawns, around buildings, and along roads to hel $p$ control unwanted vegetation (weeds), insects, fungi, and other pests. In the $\mathrm{SCI}$ study unit, herbicides and insecticides (including fumigants) were not detected at either high or moderate concentrations in the primary aquifer system.

\section{BENCHMARKS FOR EVALUATING GROUNDWATER QUALITY}

GA M A's Priority B asin Project uses benchmarks established for drinking water to provide context for evaluating the quality of untreated groundwater. A fter withdrawal, groundwater may be disinfected, filtered, mixed, and exposed to the atmosphere before being delivered to consumers. Federal and California regulatory benchmarks for protecting human health ( $M$ aximum Contaminant $L$ evel, $M C L$ ) were used for the evaluation when available. Otherwise, non-regulatory benchmarks for protecting aesthetic properties, such as taste and odor (Secondary M aximum Contaminant Level, SM CL), and nonregulatory benchmarks for protecting human health (Notification Level, NL, and lifetime Heal th A dvisory Level, HAL) were used when Federal and California regulatory benchmarks were not available.

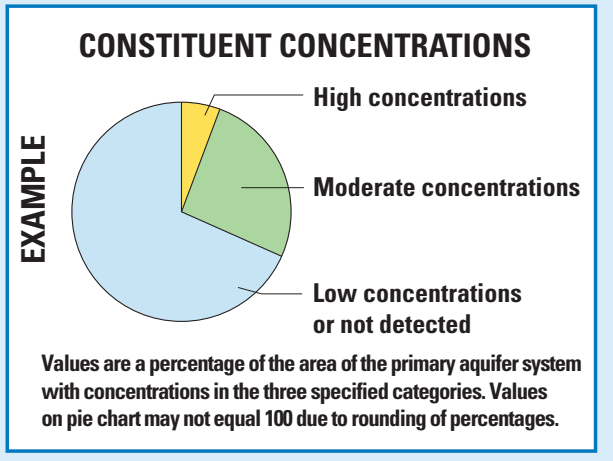

\section{High, moderate, and low concentrations are defined relative to benchmarks}

Concentrations are considered high if they are greater than a benchmark. For inorganic constituents (except perchlorate), concentrations are moderate if they are greater than one-half of a benchmark. For organic and special-interest constituents (including perchlorate), concentrations are moderate if they are greater than one-tenth of a benchmark; this lower threshold was used because organic constituents generally are less prevalent and have smaller concentrations relative to benchmarks than inorganic constituents. L ow includes nondetections and values less than moderate concentrations. M ethods for evaluating water qual ity are discussed in Parsons and others (2014). 


\section{Nitrate in the South Coast Interior Basins Study Unit}

In the $\mathrm{SCI}$ study unit, nitrate was the constituent with a health-based benchmark that was most commonly present at high concentrations. A bout $14 \%$ of the primary aquifer system had nitrate concentrations greater than the Federal MCL of 10 milligrams per liter as nitrogen. High and moderate concentrations of nitrate in groundwater generally indicate that anthropogenic sources of nitrate are present. Potential anthropogenic sources include fertilizer applied to crops and landscaping, animal waste, seepage from septic systems, and wastewater discharge.

High and moderate concentrations of nitrate were detected in all three study areas of the $\mathrm{SCl}$ study unit. Groundwater with high and moderate concentrations of nitrate was predominantly classified as oxic and as modern age (Parsons and others, 2013), which indicates the groundwater was recharged since 1952. Nitrate concentrations were greater in areas with agricultural or urban land use than in areas with natural land use. Elevated nitrate concentrations have previously been observed in the Cuyama Valley (Everett and others, 2011) and were attributed to irrigation return flows.
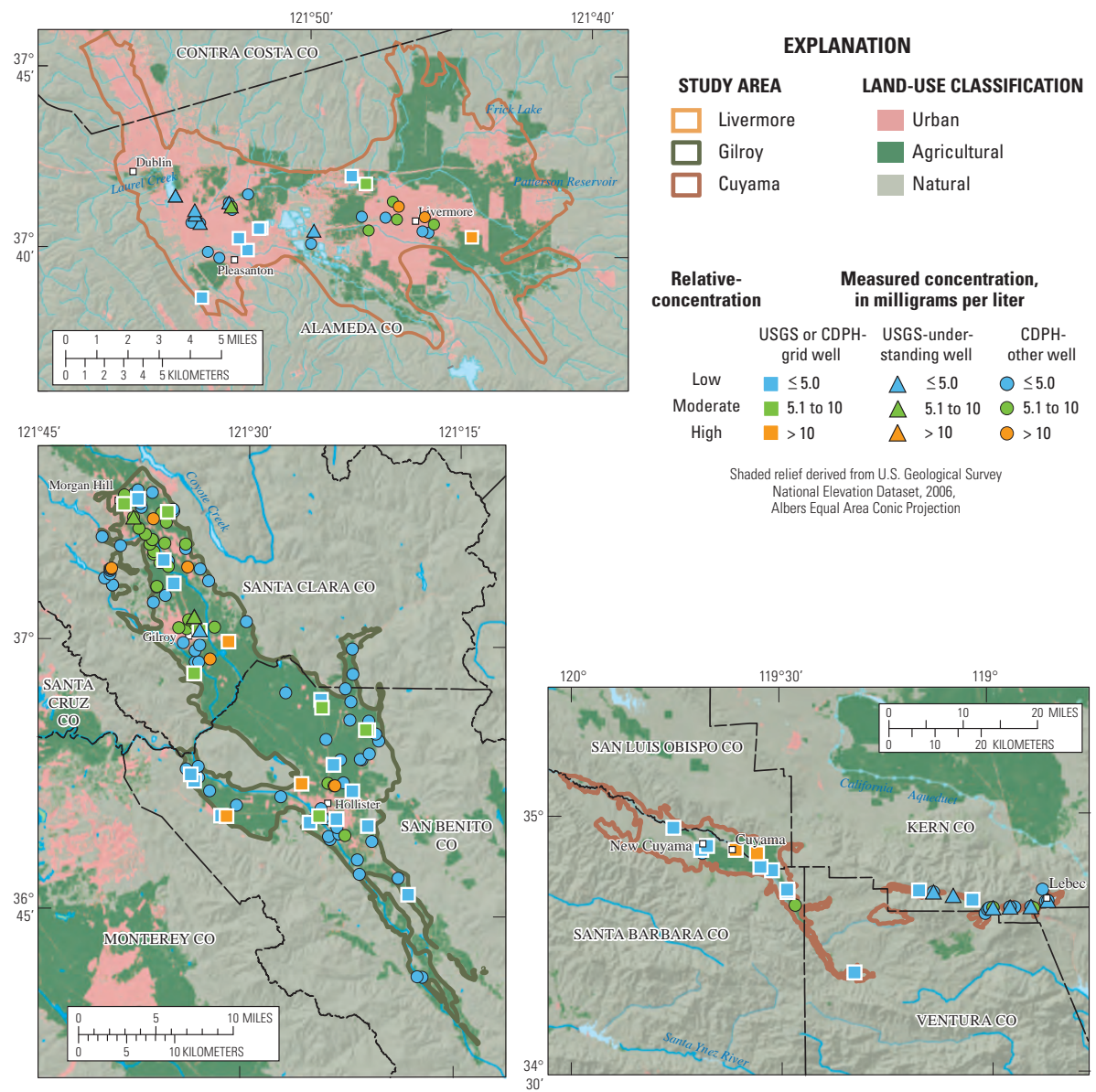

By M ary C. Parsons and K enneth B elitz

\section{SELECTED REFERENCES}

California Department of Water Resources, 2003, California's groundwater: California Department of Water Resources Bulletin 118, 246 p. Available at http://www.water.ca.gov/groundwater/bulletin118/ update2003.cfm

Everett, R.R., Hanson, R.T., and Sweetkind, D.S., 2011, K irschenmann Road multi-well monitoring site, Cuyama Valley, Santa B arbara County, California: U.S. Geological Survey O pen-File Report 2011-1292, 4 p. Available at http://pubs.usgs.gov/of/2011/1292/.

M athany, T.M ., K ulongoski, J.T., Ray, M .C., and B elitz, K enneth, 2009, Groundwater-quality data in the South Coast Interior B asins study unit, 2008- Results from the California GA M A Program: U.S. Geological Survey Data Series Report 463, 82 p. Available at http://pubs.usgs.gov/ds/463/.

Parsons, M.C., Kulongoski, J.T., and B elitz, K., 2014, Status and understanding of groundwater quality in the South Coast Interior groundwater basins, 2008-California GA M A Priority B asin Project: U.S. Geological Survey Scientific Investigations Report 2014-5023, 68 p. Available at http://dx.doi.org/10.3133/ sir20145023.
Priority Basin Assessments

GAMA's Priority Basin Project (PBP) assesses water quality in that part of the aquifer system used for drinking water, primarily public supply. Water quality in shallower and deeper parts may differ from that in the primary aquifer system. GA M A's D omestic Well Project assesses water quality in the shallower parts of the aquifer system. Ongoing PBP assessments are being conducted in more than 120 basins throughout California.

The PBP assessments are based on a comparison of constituent concentrations in untreated groundwater with benchmarks established for the protection of human health and for aesthetic concerns for drinking water. The PBP does not evaluate the quality of drinking water delivered to consumers.

The PBP uses two scientific approaches for assessing groundwater quality. The first approach uses a network of wells to statistically assess the status of groundwater quality. The second approach combines water-quality, hydrologic, geographic, and other data to help assess the factors that affect water quality. In the South Coast Interior $B$ asins study unit, data were collected by the PBP in 2008 and compiled from the CDPH database for 2005-2008. The PBP includes chemical analyses not generally required as part of regulatory compliance monitoring, including measurements at concentrations much lower than human-health benchmarks, and measurement of constituents that can be used to trace the sources and movement of groundwater.

\section{For more information}

Technical reports and hydrologic data collected for the GA M A Program may be obtained from

\section{GAMA Project Chief}

U.S. Geological Survey

California Water Science Center

6000 J Street, Placer Hall

Sacramento, CA 95819

Telephone number: (916) 278-3100

WEB: http://ca.water.usgs.gov/gama

\section{GAMA Program Unit Chief}

State Water Resources Control B oard

Division of Water Q uality

PO B ox 2231, Sacramento, CA 95812

Telephone number: (916) 341-5779

WEB: http://www.waterboards.ca.gov/gama

ISSN 2327-6916 (print)

ISSN 2327-6932 (online)

http://dx.doi.org/10.3133/fs20133088 